\title{
Chemical burns in children - admission criteria
}

\author{
Arsurile chimice la copii - criterii de internare
}

\author{
Laura Vasile1, Raluca Tătar ${ }^{1,2}$, Dan Mircea Enescu ${ }^{1,2}$ \\ ${ }^{1}$ Spitalul Clinic de Urgență „Grigore Alexandrescu“, București, România \\ 2Universitatea de Medicină și Farmacie „Carol Davila", București, România
}

\begin{abstract}
One of the most frequent causes of accidents in children are burns, regardless of aetiology, without displaying a noteworthy gender disparity, and they represent one of the most complex diseases with which a body can be afflicted.

The differences amongst patients who arrived at the emergency room, as well as those who were hospitalised on the Plastic Surgery and Burns department within the Clinical Emergency Hospital "Gr. Alexandrescu", regarding their age, gender, percentage of the afflicted body surface area, the location of the burn lesions on their bodies, have been monitored and analysed, in order to create an equation which defines the profile of the patient hospitalised within the plastic surgery departments.
\end{abstract}

Keywords: chemical burns, admission, pediatric, concentration

\section{REZUMAT}

Una dintre cele mai frecvente cauze de accident la copil este reprezentată de arsură, indiferent de etiologie, fără a prezenta vreo diferențiere notabilă între sexe, fiind una dintre cele mai complexe boli cu care se poate confrunta organismul.

Sunt urmărite și analizate diferențele din punctul de vedere al vârstei, sexului, procentului de suprafață corporală afectată, localizării leziunilor de arsură la nivelul corpului dintre pacienții prezentați în camera de gardă și cei internați pe secția de Chirurgie plastică și Arsuri a Spitalului Clinic de Urgență „Gr. Alexandrescu”, pentru a crea o ecuație care să ne definească profilul pacientului internat în secțiile de chirurgie plastică.

Cuvinte cheie: arsuri chimice, internare, pediatrie, concentraţie

\section{INTRODUCERE}

Arsurile reprezintă un accident extrem de grav, din punct de vedere psiho-social, care afectează societatea în mod negativ. Sunt ipostaze medico-chirurgicale, psihologice şi sociale foarte grave, cu risc vital, apărând posibilitatea prezenţei unor sechele mutilante, care, din cauza faptului că se produc la vârste mici, însoțesc persoana afectată pe o perioadă lungă $(1,2)$. Un studiu efectuat în Africa de Sud ne arată că aproximativ $3,2 \%$ din populaţia acestei ţări este afectată anual de arsuri, pacienţii cu vârstă mai mică de 20 ani constituind mai mult de $50 \%$ din totalul cazurilor de arsură (3).

Agentul etiologic implicat în producerea arsurilor chimice este reprezentat de o substanţă chimică, care, în contact cu ţesuturile, determină apariţia unor leziuni asemănătoare unor arsuri termice, cu necroze de coagulare a proteinelor tisulare. Arsura chimică este diferită de arsura produsă prin alte mecanisme, pentru că, pe lângă mecanismul local termic, pot apărea şi fenomene de intoxicaţie sistemică, care duc la agravarea stării generale a pacientului. Oricare ar fi substanţa chimică implicată în producerea arsurilor, gravitatea leziunilor locale de arsură este determinată de: concentraţia substanţei care vine în contact cu tegumentul; penetrabilitatea agentului chimic implicat - un exemplu este reprezentat de fosforul alb, care arde până la epuizare în contact cu aerul; acţiunea toxică sistemică specifică fiecărei substanţe chimice - acidul 
carbonic şi fosforul produc necroză hepatică, acidul picric duce la instalarea insuficienţei renale, acidul fluorhidric, prin eliberarea ionilor de fluor la nivelul ţesuturilor, determină hipocalcemie; mecanismul de acţiune a substanţei chimice; timpul de expunere la acţiunea substanţei chimice: cu cât durata este mai mare, cu atât efectele nocive sunt mai grave. Cu cât timpul de expunere la o substanţă chimică este mai mare, cu atât aceasta penetrează în ţesuturi mai profund şi se absoarbe o cantitate mai mare $(4,5)$.

În arsurile chimice, mecanismele combinate vor determina modificări anatomo-patologice şi histochimice directe, de o diversitate mult mai mare decât în cazul arsurilor termice. Procesele de colagenoliză, lichefiere, saponificare, alături de necrozele de coagulare, care sunt determinate de acţiunea directă a căldurii, imprimă particularităţile evolutive ale acestor escare (4).

Arsura reprezintă una dintre cele mai frecvente cauze ale accidentelor la vârsta pediatrică, fără a prezenta vreo diferenţiere semnificativă între sexe şi este una dintre cele mai complexe boli cu care se poate confrunta organismul, combinând dezechilibre hidro-electrolitice majore, care cu greu pot fi reechilibrate, complicaţii sistemice cu deteriorarea funcţiilor vitale, şocul postcombustional (1-4).

În prim-plan se află tipul substanţei chimice, întrucât arsura chimică poate să fie privită ca o intoxicaţie sistemică toxicologică uneori, necesitând de urgenţă, în primul rând, stabilizarea pacientului şi apoi tratarea leziunilor locale de arsură.

Chiar dacă numărul de arsuri chimice la copii este mic, complexitatea acestor arsuri ne obligă la stabilirea unui protocol terapeutic şi la îmbunătăţirea măsurilor de prevenţie.

De exemplu, în Spania, în ultimii ani, arsurile chimice reprezintă aproximativ 3\% din totalul arsurilor apărute în decursul unui an. Totuşi, aceşti pacienţi prezintă o morbiditate crescută, aproximativ $55 \%$ dintre ei necesitând intervenţie chirurgicală, mulţi pacienţi rămânând cu cicatrici la nivelul feţei, mâinilor şi toracelui. Mortalitatea în cazul arsurilor chimice este, din păcate, foarte mare, ridicându-se la aproximativ $30 \%$ din totalul numărului de pacienţi decedaţi cu diagnosticul de arsură (6).

\section{OBIECTIVELE STUDIULUI}

Studiul efectuat urmăreşte diferenţele din punctul de vedere al vârstei, sexului, procentului de suprafaţă corporală afectată, localizării leziunilor de arsură la nivelul corpului dintre pacienţii prezentaţi în camera de gardă şi cei internaţi pe secţia de Chirurgie plastică şi arsuri a Spitalului Clinic de Urgenţă „Gr. Alexandrescu“, pentru a crea o ecuaţie care să ne definească profilul pacientului internat în secţiile de chirurgie plastică.

\section{MATERIAL ŞI METODĂ}

S-a realizat un studiu retrospectiv, comparând pacienţii care s-au prezentat la camera de gardă a SCUC „Gr. Alexandrescu“ cu cei internaţi în secţia aceluiaşi spital, din punctul de vedere al vârstei, sexului, procentului suprafeţei corporale afectate de arsură, localizarea arsurilor, gradul de profunzime a arsurii, precum şi din punctul de vedere al concentraţiei substanţei chimice care a provocat leziunea de arsură.

\section{REZULTATE}

Din analiza datelor rezultate, se constată că, în primii ani ai studiului, majoritatea pacienţilor sunt încadraţi în grupa de vârstă preşcolară, această pondere menţinându-se pe parcursul anilor de studiu. Se observă că, dacă iniţial procentul pacienţilor cu vârste cuprinse între 0 şi 4 ani este de $50 \%$, acest procent scade la $36 \%$ la finalul anilor de studiu, al pacienţilor cu vârsta cuprinsă între 4 şi 7 ani rămâne relativ constantă, crescând substanţial procentul pacienţilor de vârstă şcolară, de la 30\% la 45\%, conform figurii 1 .

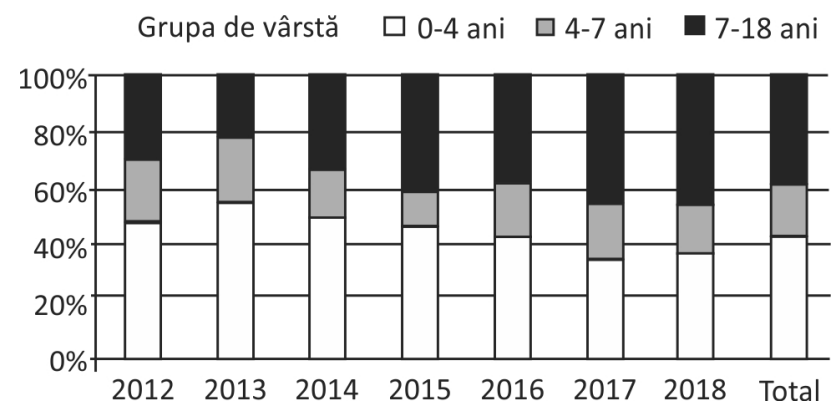

FIGURA 1. Repartiția pacienților pe grupe de vârstă pe parcursul anilor de studiu

Ca valoare medie a vârstei de apariţie a arsurilor chimice în cazul pacienţilor examinaţi la camera de gardă a SCUC „Grigore Alexandrescu“, la debutul anilor de studiu, aceasta este de 5,4 ani, dar, crescând procentul pacienţilor cu vârste peste 7 ani, a crescut şi valoarea medie a vârstei de producere a arsurilor, ajungând la 7,9 ani, aşa cum se arată în tabelul 1. 
TABEL 1. Evoluția vârstei de producere a arsurilor pe parcursul anilor de studiu

\begin{tabular}{|c|c|c|c|}
\hline An prezentare UPU & Mean & SD & SEM \\
\hline $\mathbf{2 0 1 2}$ & 5,4 & 4,169 & 1,318 \\
\hline $\mathbf{2 0 1 3}$ & 5,1 & 3,951 & 1,317 \\
\hline $\mathbf{2 0 1 4}$ & 6,0 & 4,786 & 1,382 \\
\hline $\mathbf{2 0 1 5}$ & 6,5 & 5,363 & 1,301 \\
\hline $\mathbf{2 0 1 6}$ & 5,8 & 4,203 & 1,051 \\
\hline $\mathbf{2 0 1 7}$ & 7,8 & 5,268 & 1,178 \\
\hline $\mathbf{2 0 1 8}$ & 7,9 & 5,353 & 1,141 \\
\hline Total & 6,65 & 4,883 & 0,474 \\
\hline
\end{tabular}

În figura 2 se observă că vârsta medie a pacienţilor internaţi este de aproximativ 3,36 ani, iar a pacienţilor prezentaţi la Unitatea Primiri Urgenţe este de 7,15 ani. Datele centralizate relevă faptul că vârsta pacientului este un important factor de risc: $\mathrm{cu}$ cât copilul este mai mic, cu atât riscul de evoluţie nefavorabilă a arsurii este mai mare, deci necesitatea internării este mai mare.

Vârsta (ani)

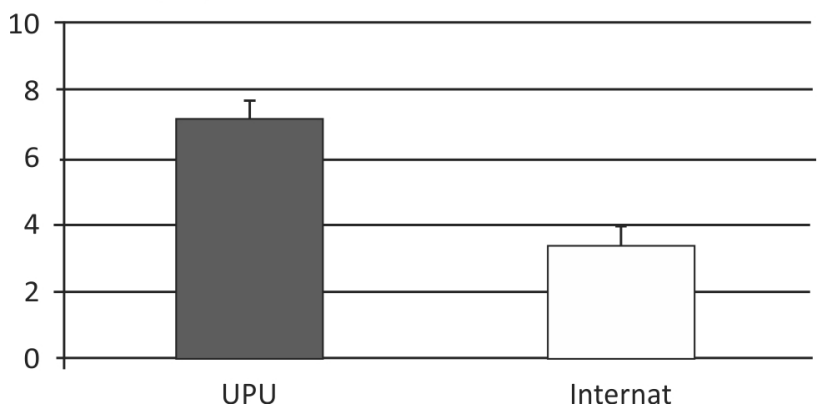

FIGURA 2. Valorile medii ale vârstei la pacienții internați şi la cei tratați în UPU

În cazul pacienţilor internaţi pe secţia de chirurgie plastică şi arsuri, vârsta medie este de 3,36 ani, cel mai mic pacient internat pe parcursul anilor de studiu având 1 an, iar cel mai mare având 9 ani tabel 2 .

TABEL 2. Valoarea medie a vârstei pacienților internați

\begin{tabular}{|l|c|}
\hline & Vârsta (ani) \\
\hline Medie & $\mathbf{3 , 3 6}$ \\
\hline $\mathbf{N}$ & 14 \\
\hline Std. deviation (SD) & 2,58 \\
\hline Std. error of mean (SEM) & 0,69 \\
\hline Minimum & 1 \\
\hline Maximum & 9 \\
\hline
\end{tabular}

Comparând cele două categorii de pacienţi studiaţi, se observă că vârsta pacienţilor este foarte importantă în decizia de internare a acestora, cu cât aceasta este mai mică, cu atât necesitatea de a rămâne internat este mai mare.

Analizând pacienţii prezentaţi la camera de gardă în perioada luată în studiu, în funcţie de sexul acestora, dintre cei 106 pacienţi ajunşi la camera de gardă a spitalului, 52 pacienţi sunt de sex feminin, reprezentând 48,6\% din totalul pacienţilor, iar 54 dintre copiii prezentaţi la Spitalul Clinic de Urgenţă „Grigore Alexandrescu“ sunt de sex masculin, reprezentând 51,4\%. Raportul total dintre cele două sexe este de aproximativ 1,04. Conform informaţiilor din baza de date, dacă la începutul anilor de studiu raportul dintre băieţi şi fete era de 1,5 în favoarea sexului masculin, la sfârşitul acestuia raportul s-a inversat, fiind de aproximativ 2 în favoarea sexului feminin - tabel 3.

TABEL 3. Distribuția pacienților de sex feminin şi masculin în anii de studiu

\begin{tabular}{|c|c|c|c|c|c|c|c|}
\hline \multirow{2}{*}{\multicolumn{2}{|c|}{\begin{tabular}{|c|} 
An \\
prezentare în \\
UPU
\end{tabular}}} & \multicolumn{2}{|c|}{ Sex } & & \multirow{2}{*}{$\begin{array}{l}\text { \% within } \\
\text { An pre- } \\
\text { zentare } \\
\text { UPU }\end{array}$} & \multicolumn{2}{|c|}{ Sex } \\
\hline & & \multirow{2}{*}{\begin{tabular}{|c|} 
Feminin \\
4 \\
\end{tabular}} & \multirow{2}{*}{\begin{tabular}{|c} 
Masculin \\
6 \\
\end{tabular}} & \multirow[b]{2}{*}{1,500} & & \multirow{2}{*}{$\begin{array}{c}\text { F } \\
40,00 \%\end{array}$} & \multirow{2}{*}{\begin{tabular}{|c|} 
M \\
$60,00 \%$ \\
\end{tabular}} \\
\hline 2012 & Count & & & & 2012 & & \\
\hline 2013 & Count & 3 & 6 & 2,000 & 2013 & $33,30 \%$ & $66,70 \%$ \\
\hline 2014 & Count & 5 & 7 & 1,400 & 2014 & $41,70 \%$ & $58,30 \%$ \\
\hline 2015 & Count & 7 & 10 & 1,429 & 2015 & $41,20 \%$ & $58,80 \%$ \\
\hline 2016 & Count & 6 & 10 & 1,667 & 2016 & $37,50 \%$ & $62,50 \%$ \\
\hline 2017 & Count & 13 & 7 & 0,538 & 2017 & $65,00 \%$ & $35,00 \%$ \\
\hline 2018 & Count & 14 & 8 & 0,571 & 2018 & $63,60 \%$ & $36,40 \%$ \\
\hline Total & & 52 & 54 & 1,038 & & & \\
\hline
\end{tabular}

Profilul pacienţilor internaţi în funcţie de sex ne arată că cei mai mulţi pacienţi implicaţi în arsurile chimice sunt de sex masculin, 8 pacienţi, cei de sex feminin fiind în număr de 6 de-a lungul celor 7 ani de studiu. Se observă, de altfel, că majoritatea pacienţilor care au necesitat internare pe parcursul anilor 2012-2018 sunt de sex masculin, 57,1\%, comparativ cu $42,9 \%$ pacienţi de sex feminin care au fost admişi în spital - figura 3 .

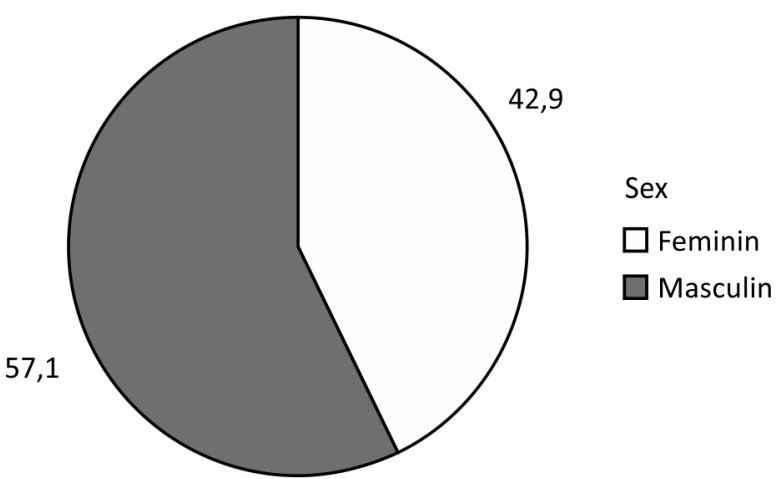

FIGURA 3. Distribuția pacienților internați în funcție de sex

În cazul pacienţilor de sex feminin, vârsta de medie la care au survenit arsurile este de 3,33 ani, la pacienţii de sex masculin aceasta fiind de 4,38 ani, observându-se deci în cazul fetiţelor o vârstă mai mică de producere a accidentelor în urma căro- 
ra apar leziunile de arsură, aşa cum reiese din tabelul 4.

TABELUL 4. Valoarea medie a vârstei pacienților internați în funcție de sex

\begin{tabular}{|c|c|c|c|c|}
\hline \multicolumn{5}{|c|}{ Vârsta (ani) } \\
\hline Sex & $\mathbf{N}$ & Medie & $\begin{array}{c}\text { Std. deviation } \\
\text { (SD) }\end{array}$ & $\begin{array}{c}\text { Std. error mean } \\
\text { (SEM) }\end{array}$ \\
\hline Feminin & 6 & $\mathbf{3 , 3 3}$ & 3,204 & 1,308 \\
\hline Masculin & 8 & $\mathbf{4 , 3 8}$ & 2,134 & 0,754 \\
\hline
\end{tabular}

Testul $\mathrm{T}$ student indepent aplicat pacienţilor internaţi în secţia de chirurgie plastică a Spitalului "Grigore Alexandrescu“ ne arată că nu sunt diferenţe semnificative statistic între vârsta medie a pacienţilor internaţi în funcţie de $\operatorname{sex}(\mathrm{p}=0,509$, $\mathrm{p}>0,05)-$ tabelul 5 .

TABEL 5. Testul T student independent pentru variația vârstei pacienților internați în funcție de sex

\begin{tabular}{|c|c|c|c|c|c|}
\hline \multicolumn{6}{|c|}{ Vârsta (ani) } \\
\hline \multicolumn{6}{|c|}{ Independent Samples Test } \\
\hline \multicolumn{3}{|c|}{$\begin{array}{l}\text { Levene's test for equality of } \\
\text { variances }\end{array}$} & \multicolumn{3}{|c|}{$\begin{array}{c}\text { T-test for equality of } \\
\text { means }\end{array}$} \\
\hline $\begin{array}{l}\text { Sex } \\
\text { Feminin. vs } \\
\text { masculin }\end{array}$ & $\mathbf{F}$ & Sig. & $\mathbf{t}$ & df & $\begin{array}{l}\text { p value } \\
\text { (2-tailed) }\end{array}$ \\
\hline $\begin{array}{l}\text { Equal variances } \\
\text { assumed }\end{array}$ & 1,301 & 0,276 & $-0,732$ & 12 & 0,478 \\
\hline $\begin{array}{l}\text { Equal variances } \\
\text { not assumed }\end{array}$ & & & $-0,690$ & 8,229 & 0,509 \\
\hline
\end{tabular}

Arsurile pot afecta multiple regiuni ale corpului uman, localizarea leziunilor de arsură fiind variată: cap, trunchi, membre. Cel mai des sunt expuse riscului de arsură membrele, lezarea acestora având o pondere de aproximativ 50\%, urmând trunchiul, cu un procent de $23 \%$, şi regiunea cervicală, cu un procent de $22 \%$. Pe parcursul anilor de studiu se păstrează raporturile dintre regiunile lezate, zona membrelor fiind cea mai afectată în urma arsurilor, conform figurii 4 .

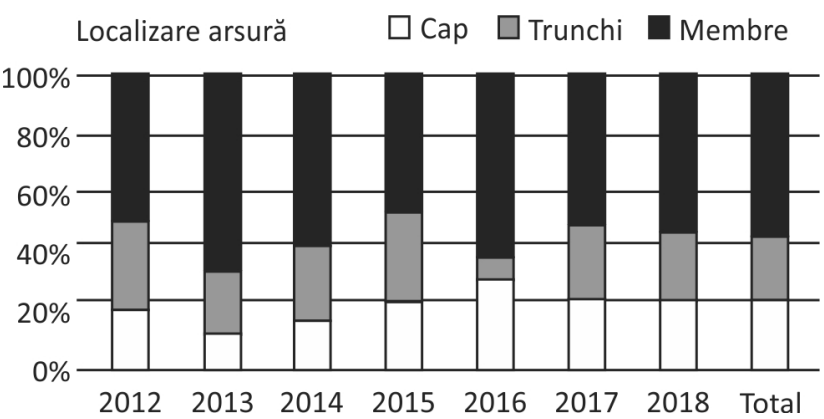

FIGURA 4. Localizarea arsurilor pe regiuni corporale pe parcursul anilor 2012-2018

Analiza datelor obţinute pe parcursul celor 7 ani de studiu cu privire la localizarea leziunilor de arsură arată că, deşi cele mai multe plăgi sunt la nivelul membrelor şi trunchiului, localizarea la cap a acestor leziuni începe să crească şi, dacă se menţine acest trend ascendent, atunci aceste leziuni la nivelul capului vor fi din ce în ce mai multe.

În cazul pacienţilor internaţi, cele mai multe arsuri sunt localizate la nivelul trunchiului şi capului, leziunile membrelor fiind comparativ cu celelalte leziuni mai puţine, aşa cum reiese din tabelul 6 .

TABEL 6. Distribuția pacienților internați în funcție de localizarea arsurii

\begin{tabular}{|c|c|c|c|c|}
\hline $\begin{array}{c}\text { Localizare } \\
\text { arsură }\end{array}$ & Frecvența & Procent & $\begin{array}{c}\text { Procent } \\
\text { valid }\end{array}$ & $\begin{array}{c}\text { Procent } \\
\text { cumulat }\end{array}$ \\
\hline Cap & 3 & 21,4 & $\mathbf{2 1 , 4}$ & 21,4 \\
\hline Trunchi & 7 & 50,0 & $\mathbf{5 0 , 0}$ & 71,4 \\
\hline Membru & 4 & 28,6 & $\mathbf{2 8 , 6}$ & 100,0 \\
\hline Total & $\mathbf{1 4}$ & $\mathbf{1 0 0 , 0}$ & $\mathbf{1 0 0 , 0}$ & \\
\hline
\end{tabular}

Astfel, arsurile trunchiului reprezintă $50 \%$, ale membrelor $28,6 \%$ şi ale capului $21,4 \%$ din totalul arsurilor cu diverse localizări internate pe secţie, cu menţiunea că cei mai mulţi pacienţi spitalizaţi pot să asocieze două sau chiar trei localizări ale leziunilor de arsură, ceea ce sporeşte complexitatea îngrijirilor acordate pacientului - figura 5 .

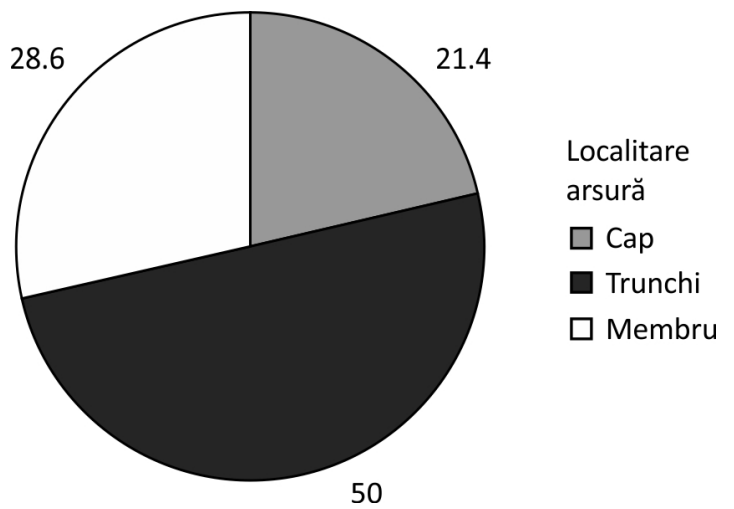

FIGURA 5. Distribuția pacienților internați în funcție de localizarea arsurii

Suprafaţa corporală afectată de arsurile chimice este, de asemenea, foarte variată. Cele mai multe arsuri afectează un procent de suprafaţă corporală considerat relativ mic, de sub 5\%, însumând un procent de $78 \%, 83$ de pacienţi, din totalul prezentărilor la camera de gardă pe parcursul celor 7ani de studiu, restul de $22 \%$, adică 23 de pacienţi, reprezentând arsuri peste $5 \%$ din suprafaţa corporală, conform figurii 6 .

Iniţial, s-a plecat de la o valoare medie a indicelui suprafeţei corporale afectate de 3,1 , ceea ce presupune că suprafaţa afectată la nivel de pacient este mai mare, comparativ cu ultimii ani ai studiului, când indicele a scăzut la 2,6 , lucru care poate fi tradus în cifre astfel: în anul 2012-2013 au fost 3, respectiv 4 pacienţi cu arsuri care afectează o supra- 


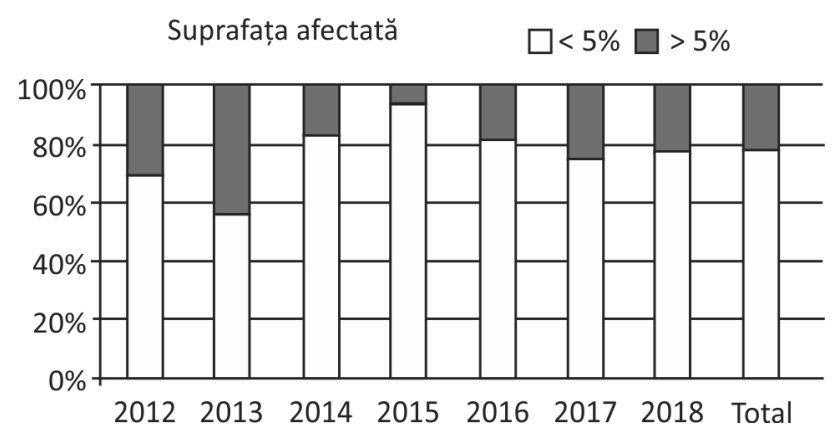

FIGURA 6. Raportul pacienților în anii 2012-2018 în funcție de suprafața corporală afectată

faţă corporală mai mare de $5 \%$ din totalul de 10 , respectiv 9 pacienţi, pe când în $2018 \mathrm{~s}$-au prezentat la camera de gardă 5 pacienţi cu suprafaţă corporală afectată mare, din totalul de 22 de pacienţi, aşa cum reiese din cele prezentate în tabelul 7 şi figura 7 .

TABELUL 7. Evoluția suprafeței corporale medii afectate pe parcursul anilor de studiu

\begin{tabular}{|c|c|c|c|}
\hline \multicolumn{3}{|c|}{ Suprafața afectată (\%) } & \\
\hline An & Mean & SD & SEM \\
\hline $\mathbf{2 0 1 2}$ & 3,150 & 2,868 & 0,907 \\
\hline $\mathbf{2 0 1 3}$ & 4,444 & 3,712 & 1,237 \\
\hline $\mathbf{2 0 1 4}$ & 2,833 & 2,847 & 0,822 \\
\hline $\mathbf{2 0 1 5}$ & 1,662 & 2,213 & 0,537 \\
\hline $\mathbf{2 0 1 6}$ & 1,875 & 1,628 & 0,407 \\
\hline $\mathbf{2 0 1 7}$ & 2,775 & 2,521 & 0,564 \\
\hline $\mathbf{2 0 1 8}$ & 2,682 & 2,418 & 0,516 \\
\hline Total & 2,625 & 2,570 & 0,250 \\
\hline
\end{tabular}

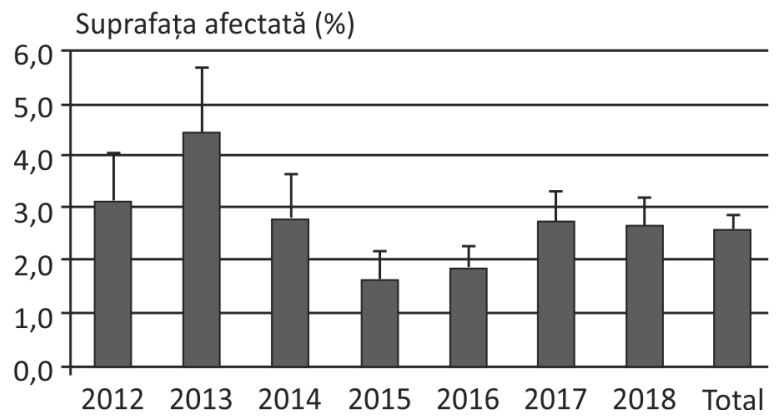

FIGURA 7. Evoluția suprafeței corporale medii afectate pe parcursul anilor 2012-2018

Tendinţa anuală privind suprafaţa corporală afectată medie a pacienţilor prezentaţi în UPU a Spitalului „Grigore Alexandrescu“ pentru arsuri chimice în perioada studiată ne arată existenţa unui trend descrescător, fără semnificaţie statistică (coeficient $b 1=-0,204$, negativ, $p=0,273)$; puterea de predicţie a modelului este $23,3 \%\left(\mathrm{R}^{2}=0,233\right)$ - tabelul 8 .
TABEL 8. Tendința anuală privind suprafața corporală afectată medie a pacienților prezentați în UPU pentru arsuri chimice

\begin{tabular}{|c|c|c|c|c|c|c|c|}
\hline \multicolumn{7}{|c|}{ Model summary and parameter estimates } \\
\hline \multicolumn{5}{|c|}{ Dependent Variable: Suprafața corporală afectată (\%) } \\
\hline \multirow{2}{*}{$\begin{array}{c}\text { Equa- } \\
\text { tion }\end{array}$} & \multicolumn{5}{|c|}{ Model summary } & \multicolumn{2}{c|}{$\begin{array}{c}\text { Parameter } \\
\text { Estimates }\end{array}$} \\
\cline { 2 - 8 } & R Square & F & df1 & df2 & Sig. & Constant & b1 \\
\hline Linear & 0,233 & 1,516 & 1 & 5 & $\mathbf{0 , 2 7 3}$ & 3,589 & $\mathbf{- 0 , 2 0 4}$ \\
\hline
\end{tabular}

Prelucrarea datelor obţinute ne arată că valoarea medie a procentului de suprafaţă corporală afectată a pacienţilor internaţi este de aproximativ $7 \%$, iar a pacienţilor prezentaţi la camera de gardă de aproximativ $2 \%$, deci în cazul afectării unei suprafeţe corporale mai mari creşte necesitatea de internare a copilului - figura 8 .

Suprafața afectată (\%)

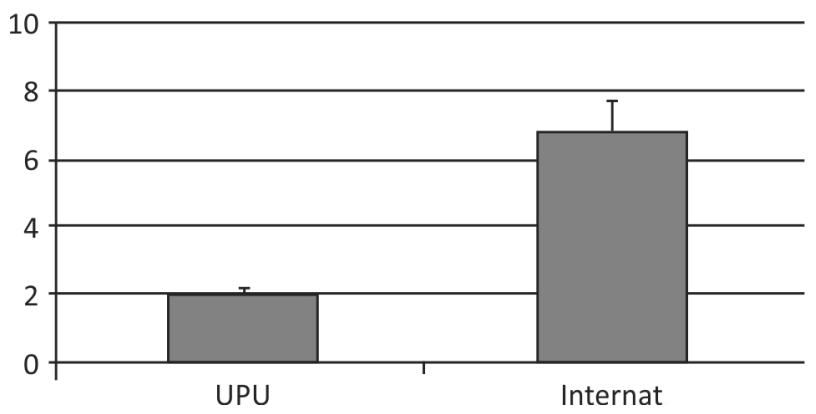

FIGURA 8. Valorile medii ale suprafeței corporale afectate la pacienții internați şi la cei tratați în UPU

Între 2012 şi 2018, la camera de gardă a spitalului, s-au prezentat 106 pacienţi cu arsuri chimice, dintre care doar 14 au necesitat internare. Admisiile în spital sunt realizate în funcţie de severitatea arsurilor, acestea 14 fiind considerate cele mai grave.

Arsurile pot prezenta diverse grade de profunzime, plecând de la o arsură superficială, cu hiperemia tegumentului până la carbonizare, cu pierdere de muşchi, oase şi alte structuri ale pielii. La pacienţii internaţi, se observă că marea majoritate a arsurilor sunt parţial superficiale sau parţial profunde, fără a avea vreo arsură care să se soldeze cu carbonizarea sau amputarea segmentului anatomic respectiv - tabel 9.

TABEL 9. Distribuția pacienților internați în funcție de gradul arsurii suferite

\begin{tabular}{|c|c|c|c|c|}
\hline Grad arsură & Frecvența & Procent & $\begin{array}{c}\text { Procent } \\
\text { valid }\end{array}$ & $\begin{array}{c}\text { Procent } \\
\text { cumulat }\end{array}$ \\
\hline IIA & 1 & 7,1 & $\mathbf{7 , 1}$ & 7,1 \\
\hline IIA-IIB & 6 & 42,9 & $\mathbf{4 2 , 9}$ & 50,0 \\
\hline IIB-III & $\mathbf{7}$ & 50,0 & $\mathbf{5 0 , 0}$ & 100,0 \\
\hline Total & $\mathbf{1 4}$ & $\mathbf{1 0 0 , 0}$ & $\mathbf{1 0 0 , 0}$ & \\
\hline
\end{tabular}


Cel mai mare procent al arsurilor pacienţilor internaţi este reprezentat de arsurile de gradul IIB-III, adică $50 \%$, urmate de arsurile de grad IIA-IIB, aproximativ $43 \%$, arsurile superficiale de grad IIA reprezentând doar 7\% din totalul leziunilor pacienţilor internaţi. Din această statistică se observă că severitatea arsurilor pacienţilor internaţi este mare, aceştia suferind arsuri profunde în majoritatea cazurilor, care necesită supravegherea lor pe o secţie de chirurgie plastică şi arsuri - figura 9 .

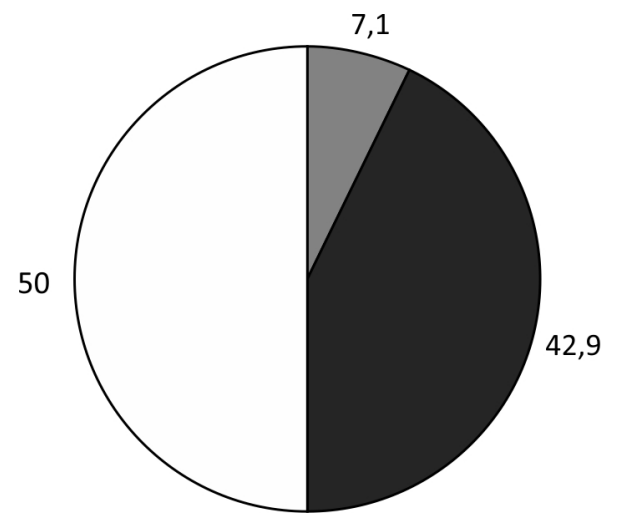

Grad arsură

$\square$ IIA

$\square$ IIA-IIB

$\square$ IIB-III

FIGURA 9. Distribuția pacienților internați în funcție de gradul arsurii suferite

Concentraţia substanţei chimice care produce arsura este foarte importantă. Substanţele chimice implicate în apariţia arsurilor la copii sunt în general de o concentrație scăzută, comparativ cu arsurile adulţilor, de multe ori accidente de muncă, unde concentraţiile agenţilor etiologici sunt mult mai mari. Testul Pearson Chi-square arată că este o asociere statistic semnificativă $(p<0,001)$ între decizia de internare a pacienţilor cu arsuri chimice şi concentraţia agentului etiologic, concentraţia mare fiind mult mai frecventă la pacienţii internaţi (aproximativ 93\%) comparativ cu cei trataţi în UPU (aproximativ 4\%).

În figura 10 se observă că la pacienţii trataţi ambulatoriu concentraţia agentului etiologic este mică, pe când la pacienţii internaţi concentraţia substanţei este mai mare.

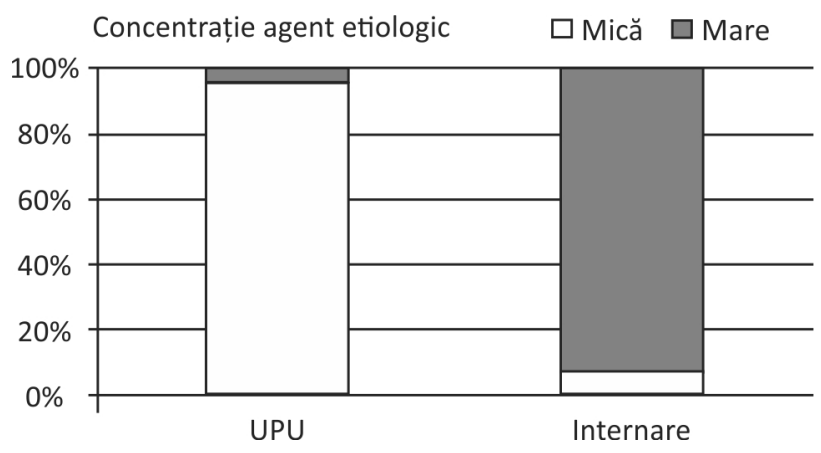

FIGURA 10. Distribuția concentrației agentului etiologic la pacienții cu arsuri chimice în funcție de internare sau tratament in UPU
În tabelul 10 se face o comparaţie între grupul pacienţilor internaţi, care conţine 14 pacienţi şi grupul pacienţilor prezentaţi la camera de gardă a spitalului, de 106 pacienţi vizavi de vârsta pacientului, procentul de suprafaţă corporală afectată, localizarea leziunii de arsură.

TABEL 10. Distribuția vârstei, a suprafeței corporale afectate şi localizarea arsurii la pacienții internați comparativ cu cei prezentați în UPU pentru arsuri chimice

\begin{tabular}{|l|c|c|c|}
\hline \multicolumn{1}{|c|}{ Parametru } & $\begin{array}{c}\text { Grup } \\
\text { Internări } \\
\text { (n= 14) }\end{array}$ & $\begin{array}{c}\text { Grup } \\
\text { Prezentare } \\
\text { UPU } \\
(\mathbf{n}=\mathbf{1 0 6})\end{array}$ & $\begin{array}{c}\text { T-test/Chi } \\
\text { square p-value }\end{array}$ \\
\hline Vârsta (ani) & $3,93 \pm 0,69$ & $6,65 \pm 0,47$ & 0,00307 \\
\hline $\begin{array}{l}\text { Suprafața } \\
\text { afectată (\%) }\end{array}$ & $6,39 \pm 0,82$ & $2,63 \pm 0,25$ & 0,00048 \\
\hline $\begin{array}{l}\text { Localizarea } \\
\text { arsurii (\%) }\end{array}$ & & & \\
Cap & 21,4 & 22,6 & 0,073 \\
$\begin{array}{l}\text { Trunchi } \\
\text { Membre }\end{array}$ & 50,0 & 22,6 & \\
\hline
\end{tabular}

TABEL 11. Testul Chi-square pentru localizarea arsurii

\begin{tabular}{|l|c|c|c|}
\hline $\begin{array}{l}\text { Chi-square tests } \\
\text { Localizarea arsurii }\end{array}$ & Value & df & $\begin{array}{c}\text { Asymp. Sig. } \\
\text { (2-sided) }\end{array}$ \\
\hline Pearson Chi-square & 5,227 & 2 & 0,073 \\
\hline Likelihood ratio & 4,838 & 2 & 0,089 \\
\hline $\begin{array}{l}\text { Linear-by-linear } \\
\text { association }\end{array}$ & 1,161 & 1 & 0,281 \\
\hline N of valid cases & 120 & & \\
\hline
\end{tabular}

Riscul sau decizia de internare poate fi estimată statistic printr-o analiză statistică specifică, care ia în calcul atât parametrii numerici continuu distribuiţi (vârsta şi suprafaţa afectată), cât şi variabile binare (logistice, cum ar fi sexul, gravitatea arsurii sau alte diagnostice secundare). Estimarea riscului sau a deciziei de a interna pacientul cu arsură chimică a fost făcută folosind analiza complexă de regresie logistică binară (BLR). Această analiză oferă o estimare clară a riscului de internare pentru arsuri chimice, luând în calcul inclusiv parametrii problematici, cum este concentraţia agentului etiologic.

În acest model, suprafaţa afectată este un predictor independent ( $\mathrm{p}$ value la Chi-square model 1 fiind $<0,001$ ), la care se adaugă concentraţia agentului etiologic ( $\mathrm{p}$ value la Chi-square model 3 fiind, de asemenea, $<0,001)$. La final, principalii contributori la ecuaţia de calcul a riscului de internare sunt, în ordinea coeficienţilor: concentraţia agentului etiologic $(\operatorname{expB}=945,37 ; p=0,011)$, sexul $(\operatorname{expB}=14,49, \mathrm{p}=0,171)$ şi suprafaţa afectată $(\operatorname{expB}=2,32, p=0,019)$. De remarcat faptul că avem un parametru determinant semnificativ pen- 
TABEL 12. Regresia logistică binară şi analiza individuală a parametrilor numerici sau binari în calculul pentru riscul de internare la pacienții cu arsuri chimice prezentați în UPU

\begin{tabular}{|c|c|c|c|c|c|}
\hline $\begin{array}{c}\text { Regresie logistică } \\
\text { binară }^{\mathbf{1}}\end{array}$ & $\begin{array}{c}\text { Predicție } \\
\text { internare (\%) }\end{array}$ & $\begin{array}{c}\text { Chi-square } \\
\text { etapă }\end{array}$ & $\begin{array}{c}\text { p-value } \\
\text { etapă }\end{array}$ & $\begin{array}{c}\text { Chi-square } \\
\text { model }\end{array}$ & $\begin{array}{c}\text { p-value } \\
\text { model }\end{array}$ \\
\hline Model 1 $^{\text {a }}$ & 96,2 & - & - & 44,520 & $<0,001$ \\
\hline Model 2 $^{\mathbf{b}}$ & 94,3 & 1,321 & 0,250 & 45,841 & $<0,001$ \\
\hline Model 3 $^{\mathbf{c}}$ & 96,2 & 18,852 & $<0,001$ & 64,693 & $<0,001$ \\
\hline Model 4 $^{\text {d }}$ & 97,2 & 2,320 & 0,128 & 67,013 & $<0,001$ \\
\hline
\end{tabular}

${ }^{1}$ Variabilă dependentă: decizia de internare. Testul Chi-square este calculat pentru contribuția parametrilor (covariate sau predictori) la model. Parametrii categorici/binari = (cat) în tabelul 13

${ }^{a}$ Covariate (predictori): Vârsta (ani) și suprafața afectată (\%);

${ }^{b}$ Covariate (predictori) adăugate la modelul 1: Profunzimea arsurii (minoră/majoră);

${ }^{c}$ Covariate (predictori) adăugate la modelul 2: Concentrație agent etiologic (mică/mare);

${ }^{d}$ Covariate (predictori) adăugate la modelul 3: Sexul pacienților (F/M).

TABEL 13. Tabel coeficienți individuali ecuație

\begin{tabular}{|c|c|c|c|c|c|c|c|c|}
\hline \multirow{2}{*}{ Variables in the equation } & \multirow{2}{*}{ B } & \multirow{2}{*}{ S.E. } & \multirow{2}{*}{ Wald } & \multirow{2}{*}{ df } & \multirow{2}{*}{ Sig. } & \multirow{2}{*}{$\operatorname{Exp}(B)$} & \multicolumn{2}{|c|}{ 95\% C.I. for $\operatorname{Exp(B)}$} \\
\hline & & & & & & & Lower & Upper \\
\hline Vârsta (ani) & $-0,024$ & 0,192 & 0,015 & 1 & 0,902 & 0,977 & 0,67 & 1,42 \\
\hline Suprafața afectată (\%) & 0,843 & 0,359 & 5,502 & 1 & 0,019 & 2,322 & 1,14 & 4,69 \\
\hline Gravitatea arsurii (cat) & $-0,754$ & 1,821 & 0,171 & 1 & 0,679 & 0,471 & 0,013 & 16,71 \\
\hline Concentrație agent (cat) & 6,852 & 2,699 & 6,446 & 1 & 0,011 & 945,368 & 4,77 & 187400,47 \\
\hline Sex (cat) & 2,673 & 1,953 & 1,875 & 1 & 0,171 & 14,489 & 0,31 & 665,43 \\
\hline Constantă & $-9,973$ & 4,833 & 4,259 & 1 & 0,039 & 0,000 & & \\
\hline
\end{tabular}

tru riscul de internare, concentraţia agentului etiologic, care, practic, stabileşte independent decizia de internare - tabel 12.

În concluzie, decizia de internare poate fi luată după un calcul conform ecuaţiei:

Scor risc internare $=$ Vârsta $($ ani) $\times 0,977+$ Suprafaţa afectată $(\%) \times 2,322+$ Profunzimea arsurii (0 minor/1 major) $\times 0,471+$ Concentraţie agent etiologic (0 mică / 1 mare) x 945,37+ Sex (0 F/1 M) x 14,4 .

\section{DISCUȚII}

Analizarea arsurilor din punct de vedere epidemiologic este foarte importantă pentru a evalua efectul măsurilor de prevenţie deja implementate şi pentru a putea stabili şi alte abordări ale acestei probleme de sănătate publică.

În acest studiu, observăm că vârsta celor mai mulţi pacienţi este cuprinsă între 0 şi 4 ani, reprezentând aproximativ $42 \%$ din totalul copiilor cu arsuri chimice, la cei cu vârsta cuprinsă între 4 şi 7 ani procentul este de $20 \%$, iar la cei cu vârsta peste 7 ani este de $38 \%$. Analiza datelor pe fiecare an şi grupe de vârstă ne indică faptul că, la începutul studiului, procentul copiilor cu vârste sub 4 ani afectaţi era de $50 \%$, acest procent scăzând la $36 \%$ în anul 2018. De asemenea, procentul pacienţilor cu vârsta peste 7 ani se situa în anul 2012 la 30\%, acest procent crescând simţitor la sfârşitul perioadei analizate la $45 \%$. Totuşi, grupa de vârstă cu risc maxim de producere a arsurilor rămâne grupa 0-4 ani. De altfel, şi în alte studii realizate la nivel mondial grupa de vârstă cuprinsă între 0 şi 3 ani este cea mai expusă. De exemplu, în studiile efectuate în provincia Sichuan, pacienţii de 0-3 ani reprezintă $72 \%$ din totalul arsurilor (7), în Shanghai, aceeaşi grupă $63,3 \%$ (8), iar în sud-vestul Chinei - grupa 0-5 ani reprezintă $85,5 \%$ dintre cazurile cu arsuri (9). Urmărind literatura de specialitate, se observă că şi în alte ţări precum Australia vârsta medie de producere a arsurilor este de aproximativ 2 ani, cu două vârfuri, la 2 ani şi respectiv 15 ani (10).

Vârsta medie a pacienţilor internaţi în centrul terapeutic din Teheran este de 5,4 ani (11), în Arizona vârsta medie este de 1,7 ani-predomină arsurile prin lichid fierbinte (12), iar în Shanghai de 3,5 ani (8). În România, vârsta medie a pacienţilor internaţi este de 3,36 ani, fiind asemănătoare cu vârsta medie a altor studii. Rezultatele analizate în cazul pacienţilor din ţara noastră ne arată, prin comparaţia celor două categorii - pacienţii prezentaţi la camera de gardă a spitalului şi pacienţii internaţi pe secţia de chirurgie plastică şi arsuri a spitalului -, că vârsta medie este semnificativ statistic mai mare la pacienţii cu arsuri chimice prezentaţi în camera de gardă - 5,4 ani ajungând şi la 7,9 ani în 2018, comparativ cu cei internaţi - 3,36 ani. 
Altă constantă analizată este sexul pacienţilor implicaţi în arsurile chimice. În studiul pregătit, iniţial raportul băieţi/fete a fost de 1,5:1 în favoarea băieţilor, după care acest raport se schimbă în favoarea fetelor, raportul băieţi/fete fiind de 1:2, la sfârşitul perioadei de studiu. Totuşi, băieţii reprezintă 57,4\% din totalul pacienţilor internaţi pe secţia de chirurgie plastică şi arsuri a SCUC „Gr. Alexandrescu“, raportul fiind asemănător cu al altor studii realizate $(7,8,11)$, o explicaţie a acestui fapt putând fi hiperactivitatea naturală a băieţilor comparativ cu fetele, curiozitatea de a descoperi mediul înconjurător (13).

Arsurile pot fi localizate la orice nivel al corpului, în studiul realizat observându-se că există diferenţe între localizarea arsurilor la pacienţii examinaţi la camera de gardă şi pacienţii internaţi pe secţie. Astfel, la pacienţii examinaţi la camera de gardă, cele mai multe arsuri sunt localizate la nivelul membrelor $-55 \%$, la nivelul trunchiului $-23 \%$, iar cap + gât $-22 \%$. La pacienţii spitalizaţi, procentul se schimbă, pe primul loc fiind leziunile la nivelul trunchiului - 50\%, membre- $28 \%$, cap + gât $22 \%$. Comparând cu alte studii, se observă că în cea mai mare parte se păstrează primul loc, adică leziunile la nivelul trunchiului, pe locul secund în unele studii fiind leziunile de la nivelul capului şi gâtului (8), în altele fiind leziunile de la nivelul membrelor (7).

În cazul pacienţilor adulţi, expuşi la substanţe chimice de concentraţie crescută, care lucrează cu cantităţi mari de substanţe chimice în mediu industrial, procentul de suprafaţă corporală afectată poate fi mare, dar la copii, în cele mai multe cazuri, suprafaţa afectată este de mici dimensiuni. Monitorizarea de pe parcursul anilor 2012-2018 relevă faptul că, în primii ani ai studiului, valoarea medie a procentului de suprafaţă corporală afectată la pacienţii examinaţi la camera de gardă a fost de $4,44 \%$, această constantă scăzând progresiv, astfel încât ajunge ca în anul 2018 să măsoare 2,41\%. Pacienţii internaţi prezintă o valoare medie a procen- tului de suprafaţă corporală afectată de 7\%. În studiul realizat de Rachel Cruz şi colaboratorii, se observă că valoarea medie a procentului de suprafaţă corporală afectată este în jur de 1\% (10). Hardwicke şi colab. arată, de asemenea, că la marea majoritate a pacienţilor $-93 \%$, atât adulţi, cât şi copii, procentul de suprafaţă corporală afectată este mai mic de 5\%. Doar 7\% dintre pacienţii internaţi prezintă arsuri cu o suprafaţă mai mare de 5\% (14). Comparând diferenţele dintre cele trei studii, se ajunge la concluzia că la noi în ţară trebuie îmbunătăţite măsurile de prevenţie a arsurilor în general.

Cel mai mare procent al arsurilor pacienţilor internaţi este reprezentat de arsurile de gradul IIB-III, adică $50 \%$, urmate de arsurile de grad IIA-IIB, aproximativ $43 \%$, arsurile superficiale de grad IIA, reprezentând doar 7\% din totalul leziunilor pacienţilor internaţi. Din această statistică, se observă că severitatea arsurilor pacienţilor internaţi este mare, aceştia suferind arsuri profunde în majoritatea cazurilor, care necesită supravegherea lor pe o secţie de chirurgie plastică şi arsuri.

Conform datelor analizate, numărul copiilor cu arsuri chimice care s-au prezentat la Unitatea Primiri Urgenţe a SCUC „Grigore Alexandrescu“ este de 106 pacienţi, iar dintre aceştia doar 14 copii necesitând internarea şi monitorizarea lor pe secţia de chirurgie plastică şi arsuri a spitalului.

\section{CONCLUZII}

Decizia de internare a copiilor cu arsuri chimice ţine cont de mai mulţi parametri, care, prin interdependenţa lor, dau naştere unei ecuaţii în care factorii cei mai importanţi sunt vârsta pacientului, procentul de suprafaţă corporală afectată, gradul de profunzime a arsurii, sexul pacientului şi concentraţia substanţei chimice implicată în producerea arsurii.

Adevărata provocare în legătură cu arsurile constă nu atât în succesul tratării arsurilor severe, cât în succesul prevenirii producerii acestora.

Conflict of interest: none declared Financial support: none declared

\section{BIBLIOGRAFIE}

1. Enescu M. Dan, Enescu Mihaela. Arsurile copilului. Bucureşti, Editura MedicArt, 2003.

2. Lascăr I, Bordeianu I, Bratu T, Dumitrescu-lonescu D, Enescu D, Florescu PI, Georgescu D, Matusz P, Mugea T, Stamate T. Principii de chirurgie plastică şi microchirurgie reconstructivă. Bucureşti: Colecţia Monografii Medicale, Editura Naţional, 2005.

3. Albertyn R, Bickler SW, Rode H. Paediatric burn injuries in Sub Sahara Africa - an overview. Burns 2006;32:605-12.

4. Enescu DM, Bordeianu I. Manual de chirurgie plastică. Ovidius University Press, 2001.

5. Herndon DN (red.). Total Burn Care, Ilth and IIlth editions. Saunders Elsevier; 1999, 2007.

6. Palao R, Monge I, Ruiz M, Barret JP. Chemical burns: Pathophysiology and treatment. Burns. 2010;36(3):295-304.

7. Liu Y, Cen Y, Chen JJ, Xu XW, Liu XX. Characteristics of paediatric burns in Sichuan province: epidemiology and prevention. Burns. 2012;38(1):26-31. 
8. Xin W, Yin Z, Qin Z, et al. Characteristics of 1,494 pediatric burn patients in Shanghai. Burns. 2006;32(5):613-618.

9. Li H, Wang S, Tan J, Zhou J, Wu J, Luo G. Epidemiology of pediatric burns in southwest China from 2011 to 2015. Burns. 2017;43(6):13061317.

10. D'Cruz R, Pang TC, Harvey JG, Holland AJ. Chemical burns in children: Aetiology and prevention. Burns. 2015;41(4):764-769.

11. Alaghehbandan R, MacKay Rossignol A, Rastegar Lari A. Pediatric burn injuries in Tehran, Iran. Burns. 2001;27(2):115-118.

12. Rimmer RB, Weigand $\mathrm{S}$, Foster KN, et al. Scald burns in young children - a review of Arizona burn center pediatric patients and a proposal for prevention in the Hispanic community. J Burn Care Res. 2008;29(4):595-605.

13. Li H, Yao Z, Tan J, Zhou J, Li Y, Wu J, Luo G. Epidemiology and outcome analysis of 6,325 burn patients: A five-year retrospective study in a major burn center in Southwest China. Sci Rep. 2017;7:46066.

14. Hardwicke J, Hunter T, Staruch R, Moiemen N. Chemical burns - an historical comparison and review of the literature. Burns. 2012;38(3):383-387. 